\title{
ДИДАКТИЧНІ ТА ПСИХОЛОГІЧНІ АСПЕКТИ РОЗВИТКУ ПІЗНАВАЛЬНИХ МОЖЛИВОСТЕЙ ШКОЛЯРІВ У ПРОЦЕСІ НАВЧАННЯ ГЕОГРАФІЇ
}

Ковчин Н. А. Дидактичні та психологічні аспекти розвитку пізнавальних можливостей школярів у процесі навчання географії.

У статті проаналізовано проблему розвитку можливостей школярів і створення умов для їхньої інтелектуальної адаптації в сучасному світі у процесі навчання. Розкрито вимоги до змісту підручника, подано грунтовну характеристику принципів структурування дидактичного матеріалу з географії.

Ключові слова: пізнавальні можливості, інтелектуальна адаптація, географічна картина світу.

Ковчин Н. А. Дидактические и психологические аспекты развития познавательных возможностей школьников в процессе обучения географии.

В статье анализируется проблема развития познавательных возможностей школьников и создания условий для их интеллектуальной адаптации в современном мире в процессе обучения, раскрываются требования к содержанию учебника, дана основательная характеристика принципов структурирования дидактического материала по географии.

Ключевые слова: познавательные возможности, интеллектуальная адаптация, географическая картина мира.

Kovchin N. A. Didactic and psychological aspects of the development of cognitive abilities of schoolchildren in learning geography.

This article analyzes the possibilities of development opportunities and school context for their intellectual adaptation in the modern world in the learning process. Disclosed the content of the textbook development factor, filed substantial characteristic of structuring principles of didactic material on geography.

Key words: educational opportunities for the intellectual adaptation, geographical picture of the world.

Нині у світі відбуваються глобальні зміни у всіх сферах життя суспільства, природи, тому виникає необхідність створення всіх умов для ефективної адаптації особистості кожного учня до постійної трансформації багатьох основних чинників зовнішнього середовища, природи, соціуму. Інтелектуальна адаптація є основою виживання, самозбереження, самореалізації особистості. У таких умовах вивчення географії як складника природничо-наукової освіти має допомагати учням глибше розуміти географічні аспекти взаємодії суспільства і природи як єдиної системи, це можливо шляхом розвитку пізнавальних можливостей школярів.

Трансформування змін у світі як об’єкт пізнання і трансформації психологічних особливостей сучасного учня як суб'єкта пізнання потребує безперервного оновлення процесу навчання географії в школі на засадах особистісно зорієнтованої парадигми і суспільно ціннісної спрямованості географічних знань. Особистісно зорієнтоване навчання зумовлює функціональний розвиток підручника 3 урахуванням індивідуальних пізнавальних можливостей та інтелектуальних здібностей учнів, який уможливить їм самостійне опанування програмного навчального географічного матеріалу [3; 7].

У процесі навчання зміст підручника слід орієнтувати не тільки на збагачення учнів науковою інформацією $з$ географії, а й на формування мотивації навчання, інтелектуальних умінь і навичок, розвиток пізнавальних можливостей загалом через систему різнорівневих навчальних завдань, адаптацію до трансформуючих умов навколишнього середовища, виховання здатності гармонійно співіснувати в сучасному соціумі.

Аналіз останніх досліджень свідчить, що до обговорення проблеми оновлення змісту процесу навчання в школі залучено багато педагогів, методистів, науковів. Проблемами оновлення змісту навчання природничих наук, підготовки новітніх підручників з географії активно обговорюються на методичних об'єднаннях, семінарах, науково-практичних конференціях [3; 7].

Колектив наукових співробітників лабораторії географічної та економічної освіти Інституту педагогіки НАПН України, конструюючи сучасні підручники, нещодавно розробив 
зміст і методичні рекомендації до елективних курсів з географії, де було визначено основну мету і завдання кожного курсу (О. Топузов, Т. Назаренко, О. Кравчук, В. Яценко, В. Ісаєва). Елективні курси з географії сприяють формуванню географічної картини світу в учнів, дають змогу поглибити, розширити і систематизувати здобуті знання з географії [4; 7].

Наукові дослідження розглядають природничо-наукову освіту як компонент загальної освіти, значне місце в якій посідає географія, важливий чинник формування образу світу в особистості та іiї інтелектуальній адаптації. М Амосов, А. Ейнштейн, І. Цехмістро вважають образ світу важливою умовою успішної діяльності, адаптації та самореалізації людини $[1 ; 2 ; 8]$. Ж. Піаже і І. Цехмістро доводять, що інтелектуальна асиміляція та акомодація є інваріантами інтелектуальної адаптації особистості в навколишньому світі [5; 7].

Meта статті - розглянути можливості розвитку пізнавальних можливостей школярів і створення умов для їхньої інтелектуальної адаптації в сучасному світі в процесі навчання в загальноосвітній школі шляхом його оновлення й оптимізації.

Розвиток пізнавальних можливостей учнів (рівень оволодіння необхідними розумовими вміннями, знаннями, мотивації) стає можливим через організацію навчальної діяльності на різних рівнях для різних типологічних груп, які формуються після комплексної психодіагностичної роботи в процесі диференційованого навчання.

Важливим для такого навчання $є$ формування основного і додаткового змісту для учнів 3 різними рівнями пізнавальних можливостей. Розроблена модель особистісно зорієнтованого навчання школярів у галузі географічної освіти передбачає для учнів із середнім рівнем пізнавальних можливостей введення додаткового змісту навчання географії, спрямованого на корекцію і розвиток пізнавальних можливостей у здійсненні продуктивної пізнавальної діяльності через систему додаткових знань і додаткових навчальних завдань 3 географії. Для учнів 3 достатнім рівнем додатковий зміст підручників з географії спрямований на розвиток потенційних пізнавальних можливостей у втіленні творчої діяльності через систему додаткових спеціальних знань 3 географії, а для учнів 3 високим рівнем пізнавальних можливостей зміст має бути спрямований на самостійну творчу реалізацію різних знань, умінь і досвіду пізнавальної діяльності з географії.

Під час розроблення дидактичних матеріалів важливо дотримуватись правила поступового ускладнення прийомів інтелектуальної діяльності. За основу доцільно брати схему, розроблену з використанням основних принципів формування рівнів поняттєвих систем, охарактеризованих Х. Шредером [9].

На схемі видно поступове ускладнення поняттєвих систем та інформації, що надходить, пов'язаної з посиленням зв'язків між поняттями як елементами інформації, збільшенням їхньої диференціації, а також з розширенням внутрішнього простору можливих альтернативних інтегративних комбінацій, на основі якого співвідносяться різні явища, об'єкти, аспекти, що вивчаються, і розробляються нові креативні форми інтерпретації їх [9].

Задля забезпечення ефективності навчання географії слід застосовувати прийоми різної складності, що спрямовані на опанування різних розумових умінь.

У процесі формування змісту навчання необхідно на кожному рівні обирати саме домінуючі розумові операції та продукти навчання, що становлять прийоми пізнавальної діяльності учнів (прийоми навчання), оскільки на всіх рівнях можуть бути введені до пізнавального процесу кожен з названих продуктів і операцій, тому що на практиці у процесі реальної пізнавальної активності учнів під час педагогічного процесу всі розумові операції та продукти, як уважає Р. Нємов, можуть діяти одночасно.

Розроблення оновленого змісту навчання здійснюється 3 урахуванням психологічної доцільності, адже і зміст географії як навчального предмета, і всі психологічні процеси об'єднує єдиний чинник - це об’єкт пізнавання - навколишній світ, географічна оболонка Землі та їі структурні складники, географічні аспекти взаємодії суспільства і природи як єдиної системи, причиннонаслідкові взаємозв'язки і залежності між географічними процесами і явищами, проблеми взаємодії природних і суспільних територіальних систем на рівні світу, регіону, конкретної місцевості. Географічна картина світу - це результат інтелектуальної діяльності свідомості й інтегруючий чинник подальшої життєдіяльності людини і подальшого процесу пізнавання.

Наприклад, географічна картина світу, образ світу, що формується в процесі навчання 3 географії, постає як динамічна цілісна інтелектуальна структура, яка допомагає учневі 
визначати й усвідомлювати правильність чи неправильність спрямування своєї життєдіяльності, встановлювати свою роль у процесі взаємодії з природою, суспільством, середовищем, створеним людиною. Своєрідним індикатором адекватності образу світу є стан здоров'я людини, рівень душевного комфорту, успішність самореалізації у суспільстві, рівень компетентності, рівень реалізації потреби самоактуалізації [1; 5]. Правильно сформована адекватна географічна картина світу, зокрема, створює сприятливі умови для самореалізації людини, успішної адаптації у суспільстві, в колективі, безпечного існування у навколишньому середовищі, серед природи.

Наукові дослідження показують, що в різних країнах образ світу формується різними способами. На створення цілісного образу світу претендують такі форми усвідомлення реальності: міфологія і релігія (донаукові форми); філософія і наука (наукові форми); мистецтво (ненаукова форма). У процесі філо- і онтогенезу у всіх цих сферах свідомості створюються специфічні картини світу: релігійна, міфологічна, філософська, наукова i художня. За твердженням спеціалістів, усі ці картини світу не є варіантами однієї картини, вони є інваріантами, отже, кожна з них відіграє певну роль у формуванні цілісного образу світу у свідомості протягом життя [5]. Це слід ураховувати авторам під час розроблення змісту підручників з географії.

Основною загальною метою організації навчання $є$ створення умов для усвідомлення, систематизації, раціоналізації набутого учнем досвіду в повсякденному житті й розкриття перед ним усього діапазону досвіду, набутого суспільством. Процес розроблення має базуватися на структуруванні змісту підручника 3 географії для формування географічної картини світу як фактора свідомості, який ефективно уможливить забезпечити оптимальний рівень психологічного комфорту, гармонійність взаємовідносин особистості учня 3 навколишнім світом, комфортне співіснування в соціумі.

Підручники з географії покликані надати змогу школярам, 3 одного боку, сформувати цілісну систему географічних знань про навколишній світ, причинно-наслідкові зв'язки між географічними процесами, явищами; 3 іншого, - опираючись на ці знання, допомогти розв'язати психологічні особистісні проблеми, вивчаючи і пізнаючи себе як частину природи, всесвіту. Це стає можливим тільки тоді, коли учень зрозуміє глибину, сутність усіх взаємозв'язків у природі і свого взаємозв'язку з нею. Тоді він відчує, що знання загальних законів природи надає йому особистої користі в інтелектуальному, соціальному i психологічному планах. Це знання надає змогу існувати в гармонії з природою, навколишнім світом і навіть суспільством як його частиною, що сприятиме його здоров'ю, адаптації, самореалізації. Взаємодію особистості й навколишнього світу можна уявити за такою моделлю: я пізнаю природу, світ, пристосовуючись до них, адаптуюсь; я пізнаю суспільство, людей, які мене оточують, пристосовуючись до них, адаптуюсь. Під час організації процесу навчання в загальноосвітній школі слід ураховувати, що взаємодія людини і довкілля полягає в тому, що природа, суспільство, вчинки самої людини впливають на неї на біологічному та інтелектуальному рівнях, а людина зазвичай адаптує до всіх трьох чинників. Адаптація постає як процес реалізації здатності пристосування організму та інтелекту до дійсності [6].

Задля оновлення всього дидактичного процесу слід розглянути проблему, що має грунтуватись на таких принципах:

1. Послідовне використання узагальненого організовуючого ознайомлення 3 явищем в цілому (первинного синтезу), поступової деталізації (аналізу), узагальнення, систематизації (вторинного синтезу).

2. Принцип поступового доповнювання. Географічний образ світу формується шляхом заповнення «порожніх ніш» у загальній схемі. Насичення деталями має відповідати віковим психологічним можливостям старшокласників і не перевищувати їх.

3. Принцип концентричності. Формування географічної картини світу у вивченні географії шляхом постійного збереження на всіх етапах у центрі уваги певного об'єкта пізнання та рівномірної поступової деталізації.

4. Принцип кумулятивності. Від початкових етапів навчання географії сама географічна картина світу радикально не змінюється, а поступово уточнюється, поглиблюється [5].

5. Принцип єдності різних картин світу. У формуванні цілісної картини світу має бути забезпеченим об'єднання на всіх етапах суттєвих елементів різних картин світу, забезпечити і 
внесок філософської, художньої, міфологічної, релігійної та практичної (яка формується в процесі життєдіяльності й потребує об'єктивування) [5].

6. Принцип врахування вікових та індивідуальних можливостей абстрагувальної, систематизуючої та іншої інтелектуальної діяльності учнів.

Під час структурування змісту навчання географії важливо зважати, що для формування адекватного образу світу у школярів доцільно використати підхід, у якому кількість складників образу світу співвідноситься з рівнями організації матерії [5]: а) матеріальна організація світу; б) жива природа; в) людське суспільство; г) людина як частина світу. Перший рівень передбачає поступове введення інформації про будову від мікро- до мегаскопічних явищ i процесів; другий - вивчення біоценотичних, популяційно-видових, організменних процесів; третій - процес взаємодії людини з суспільством, собою; четвертий - широкий діапазон психологічних, інтелектуальних, емоційно-вольових та інших процесів, їхня цілісність, взаємозв'язок між собою і глибинний взаємозв'язок біохімічних, енергетичних, психічних, інтелектуальних, ментальних процесів з навколишнім світом.

В оновленому змісті навчання блоки знань про предмети, явища природи, закономірності й закони іiі існування мають формуватись спеціально так, щоб зміст навчання ускладнюється поступово. У результаті формуються когнітивні структури, у яких фіксується частина активізованого інтелектуального досвіду учня i досить значна частина інформації, передбаченої програмою навчання з географії, яка містить засвоєні блоки спеціальних знань про предмети, явища природи, суспільства, закономірності й закони.

\section{Література}

1. Амосов Н. М. Энциклопедия Амосова. Алгоритм здоровья. Человек и общество / Н.М. Амосов. - М.: Сталкер, 2003. - 464 с. 2. Эйнштейн А. Собрание научных трудов : в 4-х т. / А. Эйнштейн; под ред. И. Е. Тамма, Я. О. Смородинского, В. Г. Кузнецова. - Т. 4. - Статьи, рецензии, письма. - М. : Наука, 1967. - 680 с. 3. Кодлюк Я. П. Шкільний підручник як організатор засвоєння навчального матеріалу / Я. П. Кодлюк // Проблеми сучасного підручника: [зб. наук. праць]. - К. : Пед. думка, 2003. - Вип. 4. - С. 10-16. 4. Назаренко Т. Г. Теоретичні і методичні аспекти сучасного підручника з курсу «Загальна географія» / Т. Г. Назаренко // Проблеми сучасного підручника: зб. наук, праць. - К.: Пед. думка, 2003. - Вип. 4. - С. 227-229. 5. Носенко Е. Я. «Картина світу» як інтегруючий та гуманізуючий фактор у змісті освіти / Е. Я. Носенко. - Дніпропетровськ: Вид-во Дніпропетров. ун-ту, 1996. - 74 с. 6. Пиаже Ж. Избранные психологические труды / Жан Пиаже. М. : Междунар. пед. академия, 1994. - 680 с. 7. Топузов О. М. Новий підручник з економічної і соціальної географії світу / О. М. Топузов // Географія та основи економіки в школі. - 2003. - № 4. С. 20. 8. Цехмистро И. 3. Холистическая философия науки / И. 3. Цехмистро. - Сумы: Университет. книга, 2002. - 363 с. 9. Schroder Н. М. Levels of information processing / H. M. Schroder, M. J. Driver, S. Streufert // Thought and Personality / Warr P.b/ ( ed.). - Baltimor Penguin Books Inc., 1970. - P. 174-191.

УДК 371.06

Людмила Лисогор

\section{ВИКОРИСТАННЯ ЕЛЕКТРОННИХ НАВЧАЛЬНИХ ПОСІБНИКІВ НА УРОКАХ ПРИРОДОЗНАВСТВА В ПОЧАТКОВІЙ ШКОЛІ}

Лисогор Л. П. Використання електронних навчальних посібників на уроках природознавства в початковій школі.

У статті аналізуються визначення поняття «електронний навчальний посібник». Розглядаються методичні, дидактичні аспекти використання електронних навчальних посібників у навчальному процесі початкової школи, розкриваються переваги електронного засобу порівняно з традиційним друкованим підручником.

Ключові слова: електронний навчальний посібник, індивідуалізація, компетентнісний підхід.

Лисогор Л. П. Использование электронных учебных пособий на уроках природоведения в начальной школе.

В статье анализируются определения понятия «электронное учебное пособие». Рассматриваются методические, дидактичные аспекты использования электронных учебных пособий в учебном процессе начальной школы, раскрываются преимущества электронного средства в сравнении с традиционным печатным учебником.

Ключевые слова: электронное учебное пособие, индивидуализация, компетентностный подход. 